\title{
Tree pollen representation in surface pollen assemblages from different vegetation zones of European Russia
}

\author{
Elena Novenko ${ }^{1 *}$, Natalia Mazei, Maria Kusilman \\ ${ }^{1}$ M.V. Lomonosov Moscow State University, Faculty of Geography, Leninskie gory 1, 119991, Moscow, Russia; \\ *e-mail: lenanov@mail.ru
}

Received: 22 April 2017/Accepted: 03 June 2017

\begin{abstract}
The paper presents the results of studies of 270 modern pollen assemblages from different vegetation zones of the East European plain. According to obtained data the ratio of the main components in pollen assemblages from forest and forest-steppe localities is characterized by higher proportion of the regional components (e.g., Betula, Alnus, Pinus) and significantly lower participation of Picea pollen and one of deciduous trees then the proportions of these species in the surrounding vegetation. Steppe vegetation is determined by higher share of non- arboreal pollen and specific floristic composition. The comparison between geographical range of tree species and maps showing distribution of their pollen show a possibility a long distance transfer of Carpinus and Fagus pollen while pollen of Quercus and Tilia occurred close to their modern geographical ranges.
\end{abstract}

Keywords: pollen analysis, modern pollen assemblages, arboreal pollen, the East European Plain

\section{Introduction}

Pollen analysis for a long time used for reconstructions of palaeolandscapes, the Pleistocene and Holocene ecosystem dynamics and human - environment interaction. The studies of modern pollen assemblages, beginning with works of M. Davis (1963) and S. Andersen (1970) until the last decades (e.g. Seppä et al. 2004; Bennet \& Hicks 2005; Bjune et al. 2005, Giesecke 2005; Mokhova et al. 2009; Lisitsyna et al. 2011; etc), have shown the importance of a regional approach to data interpretation in pollen analysis. However, a lot of questions of pollen and vegetation relationships, human impact on vegetation and palaeoclimate still remain open.

The aim of this paper is to show a relationship between pollen assemblages and vegetation of the East European Plain and to assess the possibility of the pollen transfer by wind outside the geographical ranges of arboreal species.

\section{Material and methods}

The studies of arboreal pollen representation in surface pollen assemblages from different vegetation zone is based on analyses of 270 surface samples from different regions of European Russia and adjacent countries, 65 samples were analysed by authors and pollen counting from others was derived from the European Pollen Database (EPD) (http: //www.europeanpollendatabase.net) and from the Russian pollen database (http://pollendata.org). Taiga and mixed broadleaf-coniferous forest zones are represented by 120 and 96 samples respectively. Forest steppe and steppe vegetation zones were characterised per 20 samples. 14 pollen assemblages were revealed from tundra.

Samples for pollen analysis were prepared following Moore et al. (1991), pollen diagrams (Figs. 1, 2) were constructed using Tilia 2.0.2 and TGView (Grimm 1990). Relative pollen frequency was calculated based on total terrestrial pollen, which included arboreal pollen (AP) and non-arboreal pollen (NAP), but excluded spores. 


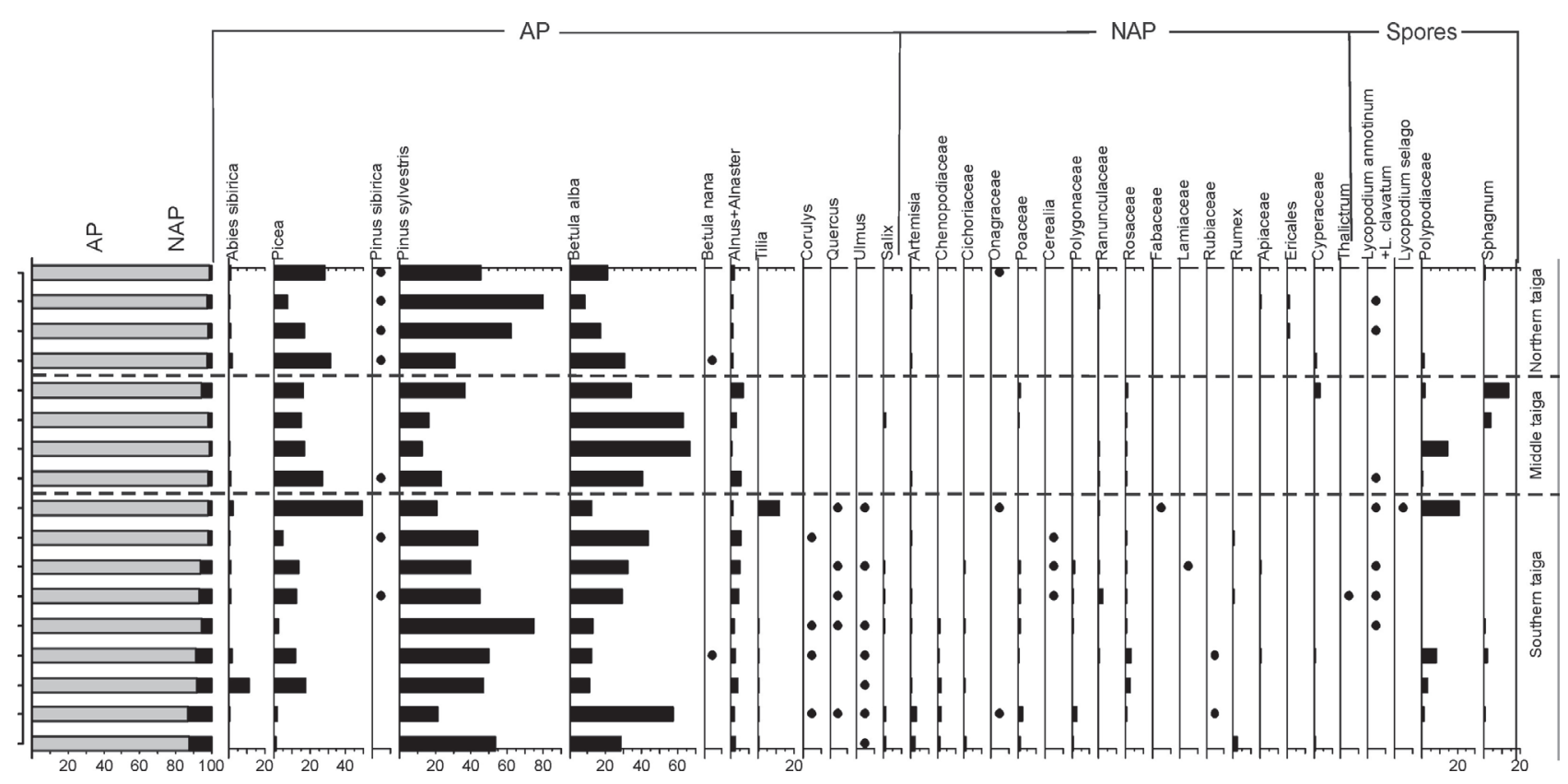

Figure 1. Pollen diagram of selected surface samples from taiga vegetation zone (modified after Novenko at al., 2017)

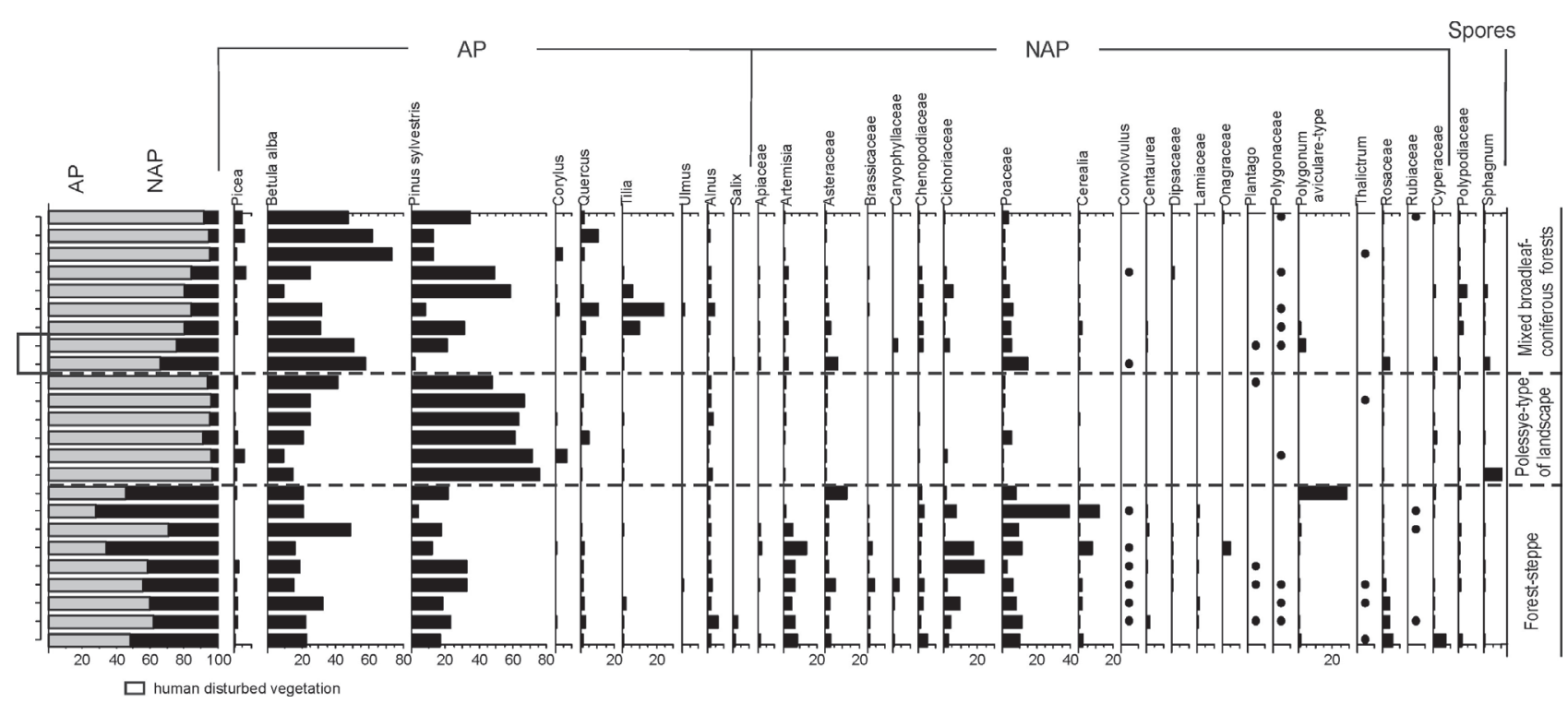

Figure 2. Pollen diagram of selected surface samples from mixed broadleaf-coniferous forest and forest steppe zones (modified after Novenko at al., 2017) 
A

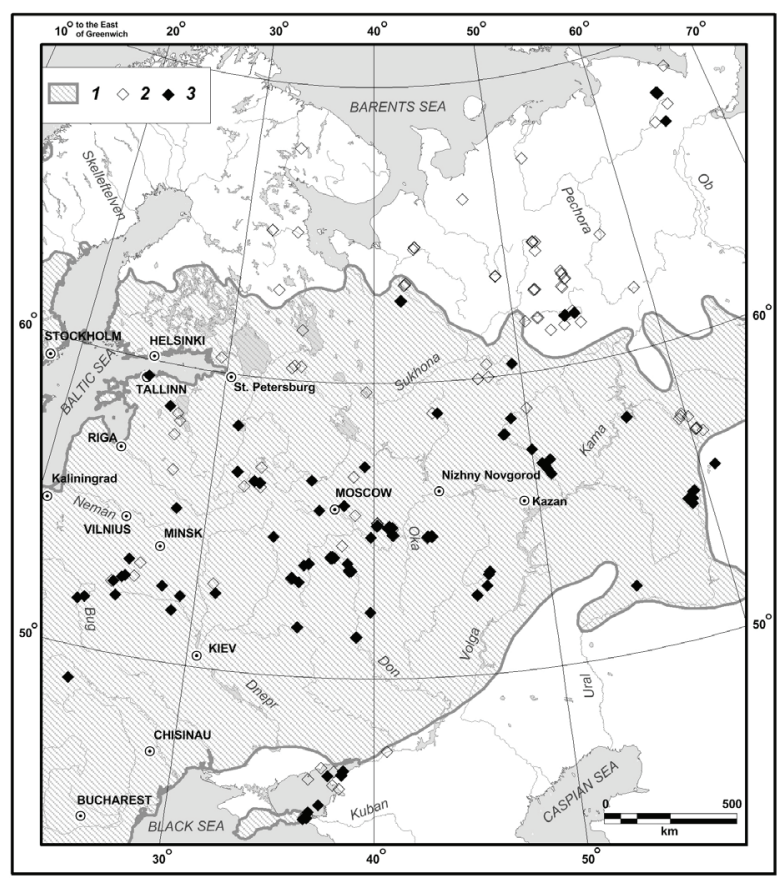

C

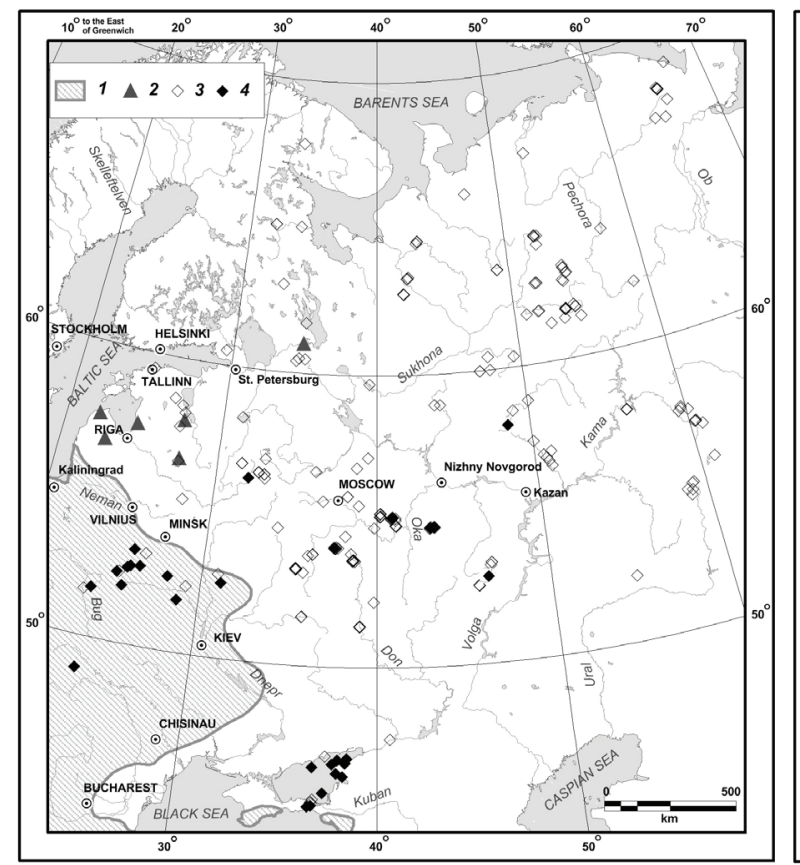

B

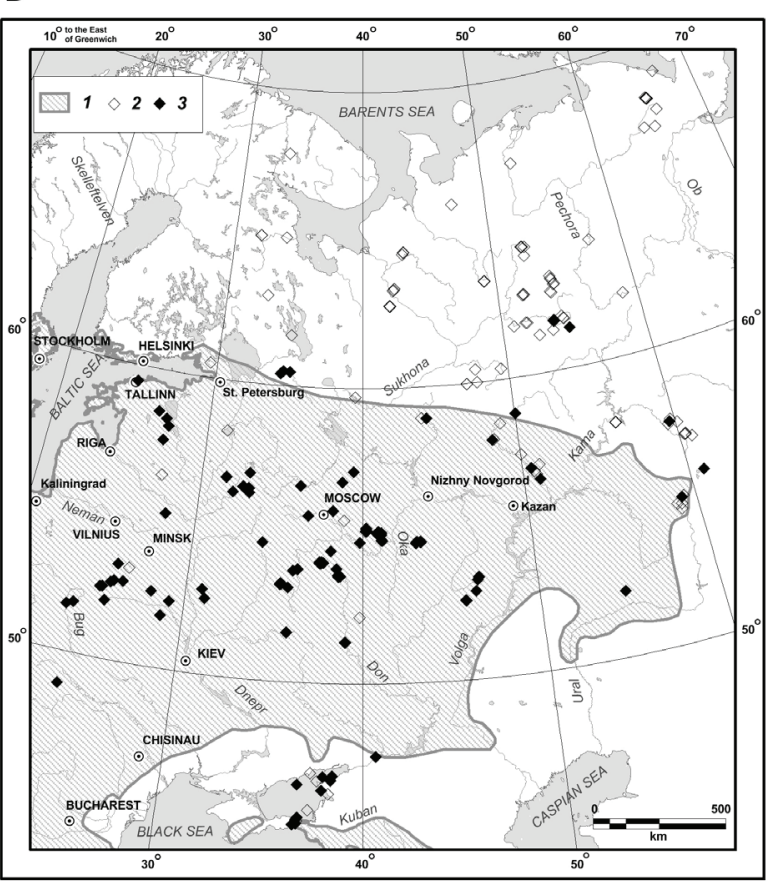

$\mathrm{D}$

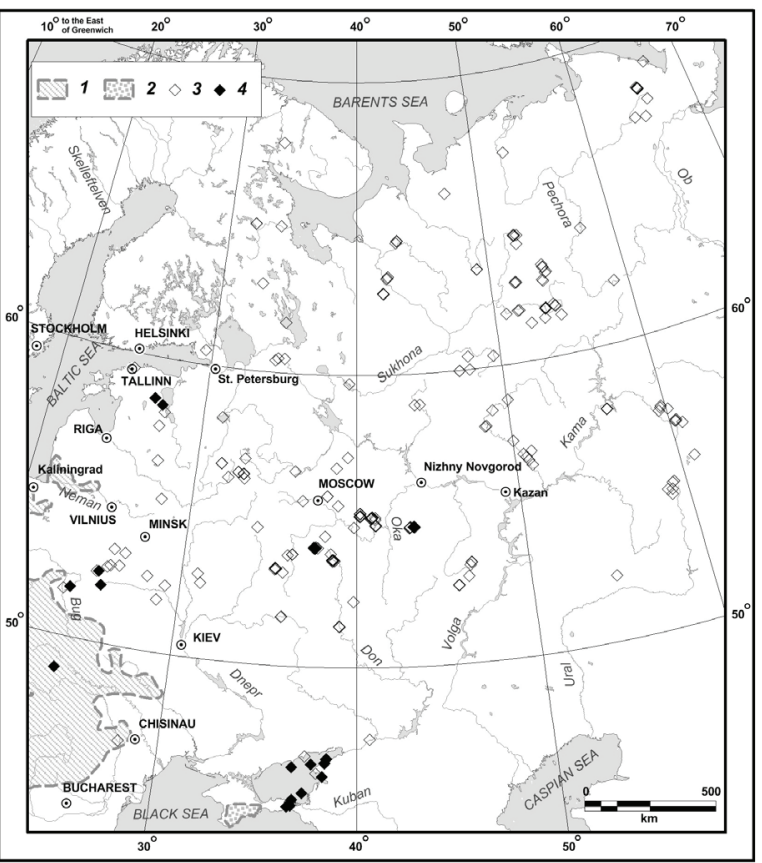

Figure 3. Modern distribution of Tilia, Quercus, Carpinus and Fagus and presence of their pollen in surface pollen assemblages

A. Tilia: 1 - geographical range of Tilia cordata, 2 - location of surface pollen samples, 3 - occurrence of Tilia pollen.

B. Quercus: 1 - geographical range of Quercus robur, 2 - location of surface pollen samples, 3 - occurrence of Qurcus pollen.

C. Carpinus: 1 - geographical range of Carpinus betulus, 2 - places, where Carpinus was introduced and naturalized (synanthropic), 3 - location of surface pollen samples, 4 - occurrence of Carpinus pollen.

D. Fagus: 1 - geographical range of Fagus sylvatica, 2 - area of growing of Fagus sylvatica and F. orientalis, 3 - location of surface pollen samples, 4 - occurrence of Fagus pollen. 
To assess the possibility of the pollen transfer by wind outside of the geographical range of tree species maps showing modern distribution of species and occurrence of pollen in surface samples were created (Fig. 3, A-D). Lime, oak, beech and hornbeam were chosen for analyses as these trees are represented on the East European Plain by single species: Quercus robur, Tilia cordata, Carpinus betulus, Fagus sylvatica. Isolated localities of Fagus orientalis in the Black sea region were shown additionally. The present day geographical ranges of species were derived from "Areals of trees and shrubs in the USSR" (1977) with corrections of modern distribution and places of the introduction of plant species by San-Miguel-Ayanz et al. (2016).

\section{Results and discussion}

Pollen assemblages from taiga and mixed broadleaf-coniferous forest zones are dominated by arboreal pollen, coniferous trees, alder and birch are most abundant. Picea abies is a permanent component of pollen assemblages from taiga forest, the percentages of Picea vary from 15 to $50 \%$ (Fig. 1). In the north-eastern part of the study region pollen assemblages include Pinus sibirica, Abies sibirica and Betula nana. Broadleaf trees (Quercus, Ulmus, Tilia, Acer) are rare in vegetation of taiga zone of European Russia, however their pollen permanently occurred in small amount $(<1 \%)$, among them Quercus pollen is most frequent. In places, where broadleaf trees occur in forest stands under canopy of spruce or pine, their percentages increase to $2-3 \%$ of AP+NAP sum.

In pollen assemblages from mixed broadleaf-coniferous forest contribution of Quercus and Tilia is 30-40\% in places within broadleaf forests and 5-10\% in mixed broadleaf-pine communities (Fig. 2). The share of Ulmus and Acer does not exceed 5\%, pollen of Fraxinus is rare. Pollen values of Corylus vary from 3 to $15 \%$. Rare pollen of Carpinus and Fagus is registered mainly in western part of the region. The extensive areas in the centre of the East European Plain are occupied by sandy plains formed by fluvio-glacial sediments and covered by pine forests, so-called Polessye type of landscapes. Pollen assemblages from these regions are dominated by Pinus pollen with very small participation of other arboreal taxa (Fig. 2).

Pollen assemblages from forest-steppe zone differ notably from spectra formed in forest vegetation. The proportion of herb pollen increased to $40-60 \%$. Artemisia and Poaceae are the most abundant; species typical for meadow-steppe vegetation take a conspicuous part in the spectra. Among trees the permanent components of pollen assemblages are Betula, Alnus and Pinus. The share of broadleaf trees does not exceed 3\%. The comparison of composition of pollen assemblage with spatial pattern of vegetation show that arboreal pollen percentages could be in 1.8-4.5 times higher then share of woodlands in plant cover. In pollen assemblages from steppe zone, taken from treeless localities, the proportions of arboreal pollen decrease to $20 \%$, that is represented mainly by Pinus, Betula and Alnus, wind pollinated tress with high pollen productivity. Pollen of broadleaf tress occurred sporadically. In marine sediments of the Sea of Azov an amount and diversity of tree pollen increased obviously due to pollen transport by rivers (Matishov et al. 2013).

According to obtained data the ratio of the main components in pollen assemblages from forest localities is distorted due to the high share of the regional component represented by plants with high pollen productivity and dispersal (e.g., Betula, Alnus, Pinus). At the same time, the participation of spruce and deciduous broadleaf tree species in the spectra is lower than the share of these samples in the surrounding forest. Besides, the proportion of regional pollen component in assemblages is much higher in samples taken from treeless areas and in floodplains than in samples taken under the forest canopy.

The comparison between geographical range of tree species and maps showing the distribution of their pollen show that pollen of Quercus, Tilia, Carpinus and Fagus is present in the most sites within their geographical ranges. Pollen of Tilia is present in area about $150 \mathrm{~km}$ around its geographical distribution, with exception of two sites in Polar Ural, about $850 \mathrm{~km}$ from its northern boundary (Fig. 3 -A). Outside range pollen of Quercus occurs in a few sites not far from the boundary of its range (Fig. 3 B). Pollen of Quercus in sites near St. Petersburg is probably belonging to planting oak trees. One isolated finding of Quercus pollen is located in Komi Republic, in $400 \mathrm{~km}$ north from its modern range.

Pollen of Carpinus was recorded beyond its distribution in several sites in the Sea of Asov region (plantation of hornbeam), and in a number of sites in Tver', Tula, Kirov and Ryazan' region and Mordovia Republic (Fig. 3 - C). The maximal distance, which Carpinus pollen was transported to the East, is about $720 \mathrm{~km}$. Pollen of Fagus was found in marine sediments of the Sea of Azov (probably, Fagus orientalis), in several sites in Belarus and Estonia, where it could be produce by beach planting in parks. Remote places of occurrences of Fagus in surface pollen assemblages are located in Tula and Moscow regions and the most distant - in Mordovia Republic, about $1200 \mathrm{~km}$ to the East (Fig. 3 -D). The obtained results allow us to conclude that pollen of Carpinus and Fagus can be transported by wind over long distances that that should be considered by interpreting fossil pollen assemblages. 


\section{Acknowledgements}

This study was supported by grant of the Russian Science Foundation (Grant 16-17-10045).

\section{References}

Andersen S.T., 1970, The relative pollen productivity and pollen representation of north European trees, and correction factors for tree pollen spectra, Danmarks geologiske Undersøgelse, Series II 96: 1-99.

Arealy derevjev i kustarnikov SSSR [Areals of trees and shrubs of USSR], 1977, Nauka-press, Moscow.

Bennett K.D. \& Hicks S., 2005, Numerical analysis of surface and fossil pollen spectra from northern Fennoscandia, Journal of Biogeography 32: 407-423.

Bjune A.E., Bakke J., Nesje A. \& Birks H.J.B., 2005, Holocene mean July temperature and winter precipitation in western Norway inferred from palynological and glaciological lake-sediment proxies, The Holocene15: 177-189.

Davis M.B., 1963, On the theory of pollen analysis, American Journal of Science 261: 897-912.

Giesecke T., 2005, Holocene forest development in the central Scandes Mountains, Sweden, Vegetation History and Archaeobotany 14: 133-147.

Grimm E.C.A., 1990, TILIA and TILIA*GRAPH.PC spreadsheet and graphics software for pollen data, INQUA Working Group on Data-Handling Methods, Newsletter 4: 5-7.
Lisitsyna O.V., Giesecke T. \& Hicks S., 2011, Exploring pollen percentage threshold values as an indication for the regional presence of major European trees, Review of Palaeobotany and Palynology 166: 311-324.

Matishov G., Kovaleva G., Novenko E., Krasnorutskaya K. \& Pol'shin V., 2013, Paleogeography of the Sea of Azov region in the Late Holocene (reconstruction by diatom and pollen data from marine sediments), Quaternary International 284: 123-131.

Mokhova L., Tarasov P., Bazarova V. \& Klimin M., 2009, Quantitative biome reconstruction using modern and late Quaternary pollen data from the southern part of the Russian Far East, Quaternary Science Reviews 28: 2913-2926.

Moore P.D., Webb J.A. \& Collinson M.E., 1991, Pollen Analysis, Blackwell, Oxford.

Novenko E.Y., Mazeil N.G. \& Zernitskaya V.P., 2017, Modern pollen assemblages from protected areas of European Russia as a key to interpreting the results of paleoecological studies, Nature Conservation Research 2(2): 55-65.

San-Miguel-Ayanz J., de Rigo D., Caudullo G., Houston Durrant T. \& Mauri A. (Eds.), 2016, European Atlas of Forest Tree Species, Publication Office of European Union, Luxembourg.

Seppä H., Birks H.J.B., Odland A., Poska A. \& Veski S., 2004, A modern pollen-climate calibration set from northern Europe: developing and testing a tool for palaeoclimatological reconstructions, Journal of Biogeography 31: 251-267. 